\title{
9 \\ MOVE TO AN AUSTRALIAN SHAREHOLDING
}

While visiting Sydney in 1960, a London Consolidated Gold Fields director, Donald McCall, asked his driver to stop the company Daimler near the Sydney Harbour Bridge. McCall got out of the car and remarked of the view back to Circular Quay, 'this is the dress circle, we must build an office here'. ${ }^{1}$ This duly occurred. Consolidated Gold Fields (Australia) (CGFA) accepted a proposal by a consortium of architects in December 1963 for the design and construction of a suitable corporate office building, located at the opposite end of Circular Quay to where meetings in the AMP building were held. The company's presence and ambitions in Australia were symbolised by the opening in 1966, with Sir George Harvie-Watt in attendance, of Gold Fields House which stood impressively on Circular Quay at 1 Alfred Street with expansive views of Sydney Harbour. Sidney Segal played a major role in the planning of the company's landmark building and oversaw the establishment of its art collection, which included works by Russell Drysdale, Arthur Boyd, Sidney Nolan and Jon Percival. Annual general meetings were held in the Rhodes Room, with a portrait of the great man reminding those present of the company's origins. A company annual report over a decade later proudly described Gold Fields House as 'one of the most prestigious buildings in Sydney', while the symbolic importance of this corporate presence was conveyed by Brian Massy-Greene

1 I am appreciative to Michael Gleeson-White, a former director of Commonwealth Mining Investments, for this insight (Gleeson-White, personal communication, 6 October 2017). Gold Fields House was designed by architects Mainline-Dillingham-Haunstrup and was one of the first multistorey buildings to be constructed in Sydney. The architects commissioned artist White to capture various stages of the construction of the building, while photographs of its progress were common (White, The Gold Fields House Story). 
to a meeting of Consolidated Gold Fields' executives in Scotland in 1964, when he stated: 'if we ever wanted to put ourselves on the map quickly, this is certainly one of the ways of doing it'. ${ }^{2}$ It was a fitting year for this new corporate presence to be established.

A board meeting of CGFA on 31 August 1966 gave consideration to a planned extraordinary general meeting of shareholders, to be held on 12 September 1966 to convert CGFA to a public company. This was approved and, in October 1966, CGFA issued 5 million ordinary shares at $A \$ 2.50$, raising $A \$ 12.5$ million and providing 22.7 per cent of the total issued capital of the company, now styled Consolidated Gold Fields Australia Ltd to Australian shareholders. The high expectations for this new British-Australian mining house were reflected in the offer for shares being oversubscribed; after the offer formally opened at 10 am on 18 October, it closed one minute later, and the company experienced 'phenomenal turnover' in its first month of trading on the Australian share market. ${ }^{3}$ Part of the funds raised by the listing were used to reduce indebtedness to Gold Fields Mining \& Industrial and the remainder applied to the Mount Goldsworthy project, where the company had an obligation to commit a further A $\$ 9.5$ million. The value of its investment in Mount Goldsworthy plus the market value of its various share investments totalled A $\$ 28.4$ million. In 1966, CGFA recorded a net profit after tax of $A \$ 2.9$ million; profit increased the following year to $A \$ 4.1$ million, mainly due to the increased contribution from Mount Goldsworthy and Mount Lyell.

Harvie-Watt retired as chairman to allow Massy-Greene to assume the dual roles of chairman and managing director of the Australian subsidiary. Since the original directors, who included Keith Cameron and Tom Owen, there were additions to the board, including Segal as an executive director, JM Burnett, GM Niall and Sir Daniel McVey. ${ }^{4}$

2 Consolidated Gold Fields Australia Limited, 13th Annual Report, 1979, p. 4; JB Massy-Greene, 'Gold Fields in Australia', in Consolidated Gold Fields Limited, 'Speeches Given at the Group Conference Held at Gleneagles Hotel, Scotland on 2-9 July, 1964', p. 154.

3 Consolidated Gold Fields Australia Limited, 'October 18th 1966, News Release'; The Sydney Stock Exchange Limited, 20 February 1967, UMA, Stock Exchange of Melbourne, 1987.0138, Box 70, L. Folders, Secretary (Companies).

4 JM Burnett was the chairman of Commonwealth Mining Investments, as well as managing director of EMI (Australia) Ltd. Gerald Mansfield Niall was a solicitor, barrister at the Middle Temple Inn and partner of Blake \& Riggall, chairman of National Mutual Life Association of Australasia and company director of Mount Lyell Mining and Railway Company, Volvo Australia, LM Ericsson, Elder Smith Goldsborough Mort, Reed Consolidated Industries, Elders Finance and Investments, and ANZ Banking Group. Sir Daniel McVey's experience is conveyed in Chapter 7, footnote 3 ('Gold Fields Appoints Three New Directors', 15 December 1966, UMA, Stock Exchange of Melbourne, 1987.0138, Box 70). 


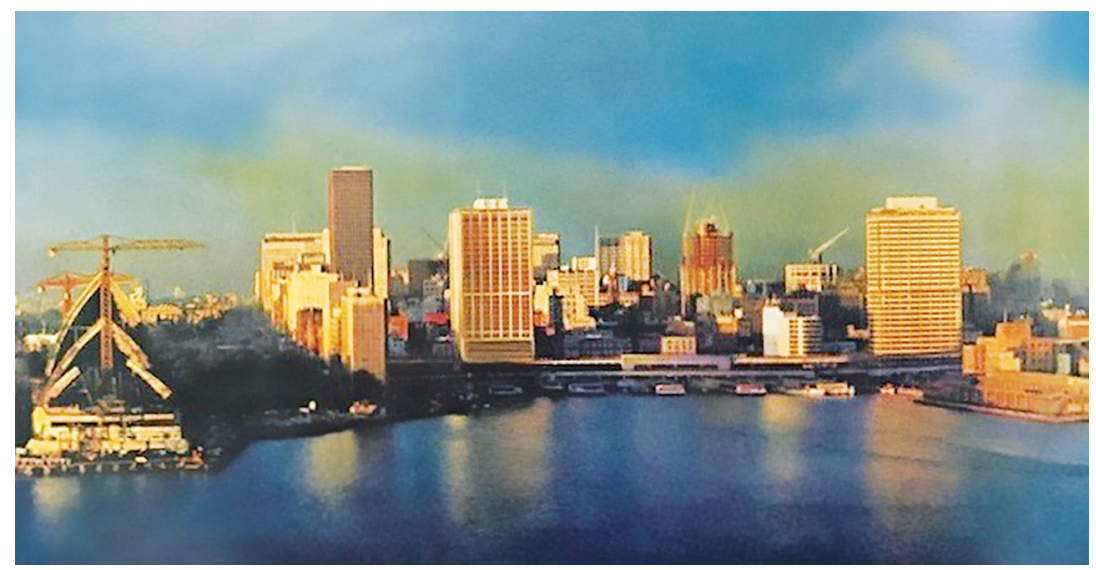

Figure 37. Gold Fields House (right), opened in 1966.

Source: 'The Gold Fields Group, Australian Edition', UMA, 1968.0018, Box 67.

Consolidated Gold Fields had contributed capital of A $\$ 24.5$ million to CGFA since its establishment in 1960, with the market value of its investments increasing to $\mathrm{A} \$ 45.6$ million. ${ }^{5}$ The Australian subsidiary company represented 18 per cent of Gold Fields' total profit and 18 per cent of group assets worldwide. Apart from the investments and shareholding already referred to, CGFA also maintained direct investments in lead, zinc, silver and copper through shareholdings in EZ Industries, Mount Morgan Mines, Mount Isa Mines, New Broken Hill Consolidated and North Broken Hill North, and the industrial shares of Broken Hill Proprietary and Imperial Chemical Industries.

A solid foundation for the company's growth in Australia had been established in a period of six years, encompassing a broad suite of minerals and investments in manufacturing, and a majority interest in Commonwealth Mining Investments. The capabilities of the board and management had been expanded and an Australian shareholding introduced. The prospects for the company were favourable. Further growth in the portfolio occurred but with challenges imposed by economic and market conditions, as well as by inherent deficiencies in the business based on a model of direct, majority shareholdings in most of its investments. 
This text is taken from Consolidated Gold Fields in Australia: The Rise and Decline of a British Mining House, 1926-1998, by Robert Porter, published 2020 by ANU Press, The Australian National University,

Canberra, Australia.

doi.org/10.22459/CGFA.2020.09 